\title{
Factors That Might Lead to Corruption: A Case Study on Malaysian Government Agency
}

\author{
Sharifah Liyana Marissa Malik Syed Abdul ${ }^{1}$, Haslinda Yusoff ${ }^{1} \&$ Nafsiah Mohamed $^{2}$ \\ ${ }^{1}$ Faculty of Accountancy, Universiti Teknologi MARA, Malaysia \\ ${ }^{2}$ Accounting Research Institute, Universiti Teknologi MARA, Malaysia \\ Correspondence: Haslinda Yusoff, Faculty of Accountancy, Universiti Teknologi MARA, Malaysia.
}

Received: April 20, 2019

Accepted: May 7, 2019

Online Published: May 19, 2019

doi:10.5430/ijfr.v10n3p216

URL: https://doi.org/10.5430/ijfr.v10n3p216

\begin{abstract}
Corruption has hindered the effectiveness of customs administrations in many developing countries. In the $21^{\text {st }}$ century, a new problem has arisen which is the rise of international terrorism. Usually, these criminal corruption activities will happen at the border points of a country. This is where the criminal operators offer bribes to the customs officials to allow them to smuggle illegal items into the country. This has posed a huge risk to both the internal and international securities of many countries. This paper seeks to investigate the factors that may influence corruption in organizational procedures that occur in Malaysia. Given the importance of government agency and its accountability, internal control and discretionary power, this paper focuses on these factors in the effort to combat corruption, increase moral awareness and narrow the opportunities for corrupt practices. Specifically, this study found that there are significant relationships between the level of accountability, internal control, discretionary power and the perception on corruption. The result also indicated that corruption flourishes in a situation where the accountability of agents to the principal is weak, when agents have low internal control and when the agents have great discretion.
\end{abstract}

Keywords: corruption, customs, level of accountability, internal control, discretionary power

\section{Introduction}

Corruption is a serious problem that relates to an unfair practice that damages the reputation of the state and weakens the economy. Malaysia's government has established Malaysian Anti-Corruption Commission (MACC) in order to investigate and prosecute corruption cases in public and private sectors. Despite that, corruption cases are still prevalent and most of them involve public officials as these individuals generally have greater authority in the public sector.

The Royal Malaysian Customs Department is a government agency responsible for administrating Malaysia's indirect tax policy. In other words, the Royal Malaysian Customs Department is formed to collect revenue efficiently and help with the expansion of trade and industry through a continuous facilitation, while enhancing legal compliance to safeguard Malaysia's economic, social and security interest (Customs Annual Report, 2015).

According to the Customs Annual Report 2015, the report contains the list of disciplinary offenses committed by the Royal Malaysian Customs officials. Some of the disciplinary offenses include absent from duty, corruption, abuse of power, drug abuse, political activity, ignoring customs procedures, and ignoring code of conduct. Figure 1 shows the summary of disciplinary offenses that occur from 2013 until 2015. 


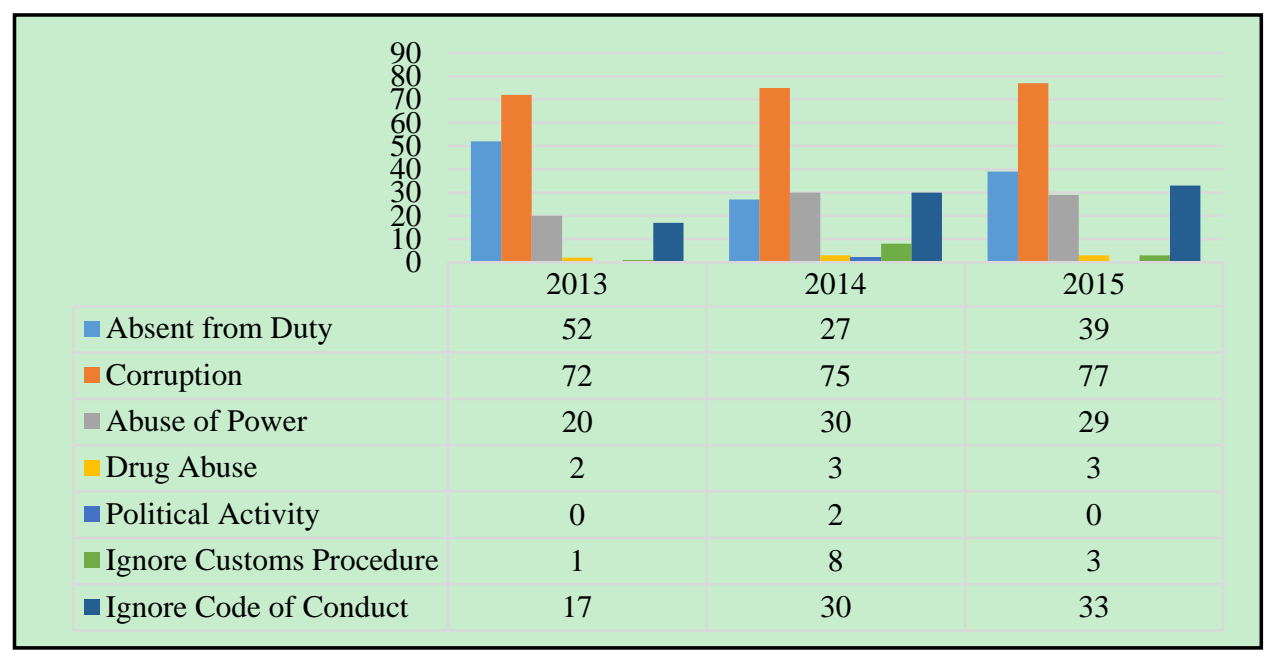

Figure 1. Summary of customs disciplinary offenses

Based on Figure 1, it clearly shows that the greatest disciplinary offense committed by the customs officials throughout the year 2013 until 2015 is corruption. These offenses show that even though the Code of Ethic and Code of Conduct have been implemented in the Royal Malaysian Customs Department by the Director General of Customs, Dato' Sri Khazali Bin Haji Ahmad, yet customs officials still ignore these policies and override them at will. Thus, it is crucial to investigate this matter because it raises the question: Do the Royal Malaysian Customs Department officials follow their Code of Ethic and Code of Conduct or are these codes merely acting as a form of window dressing?

This study assesses the possible factors that might lead to corruption in Royal Malaysian Customs Department through level of accountability, internal control and discretionary power within the organization. It also examines the relationship between the level of accountability, internal control, and discretionary power with the perception on corruption by the Royal Malaysian Customs Department. The outcomes of this study may help in creating awareness towards fighting corruption amongst government officers.

In the next section, this article begins with a discussion of the background literature, underpinning theory and development of the hypothesis. This is followed by an overview of the methodology used. The findings are then discussed before the summary and conclusions are drawn.

\section{Theoretical Background}

Corruption is simply defined as the misuse or abuse of power by a public officer for private gains (World Bank, 1997). A public officer is said to have misused his power for a private gain when he accepts, solicits, or extorts a bribe. Lambsdorff (2007) stated that corruption is misuse of public power for private benefit. The common definition of corruption includes the 'outright diversion and conversion of public funds for private use by public officials' (Nwabuzor, 2005, pp.122), 'the illegal use of power for personal gain' (Zimring and Johnson, 2005, pp.793) and 'the abuse of public trust for private gain' (Tadaro and Smith, 2003, pp.711). Certainly, these definitions involve all activities in which public officials use their power not for the public benefit, but for their own gain. Thus, to precisely define corruption in one term is rather difficult because many organizations give different definitions with regards to corruption. However, this study accepts all the above definitions. In essence, the definitions carry the idea of a public officer contravening governing rules for his own private benefit through acts of bribery, extortion and theft of public assets. Within the context of customs, corruption would involve the misuse of power by customs officials for their own personal gain.

According to Husted (1994), there are two cases of corruption, namely: "against the rule" corruption and "according to rule" corruption. The "against the rule" corruption occurs when the bribe is paid to obtain services which the official is prohibited from providing. This includes practice such as a customs officer granting entry of illegal items once he is paid a large sum of money by customers. Meanwhile, "according to rule" corruption occurs when an official receives private gains illegally for doing something which he or she is already required to do by law. Cases 
whereby a customs officer asks the customer to pay a huge sum of money in order to expedite the customer's tariff payment is an example of "according to rule" corruption.

\subsection{Level of Accountability}

Accountability is an obligation of an individual or organization to accept responsibility, to account for its actions and activities, and to disclose any private matter in a transparent manner. It also includes the responsibility for money and other entrusted properties. Palmer (2000) states that accountability is crucial for good governance and that it holds government officials to be responsible for their actions in public management. Accountability is an essential factor in reducing corruption. This is because the concept of accountability relates to the main purpose of why rules and regulations are put in place to begin with. Thus, people who administer the rules must be held responsible for their actions. Moreover, accountability has a counter effect on corruption in the sense that when more people are being held accountable for their actions, the less likely they will engage in corrupt activities (Myint, 2000; Taruvinga, et al. 2017).

According to Ndonga (2013), many cases of customs corruption resulted from ineffective accountability. Ndonga (2013) stated that there are two factors in ineffective accountability which are failure to govern the existing rules and failure to correctly apply the rules. Firstly, to failure to govern the existing rules is where the rules imposed is irrelevant compared to the potential benefits that can be gained when someone engages in corrupt practices. Customs corruption has continued to exist as customs officers are given the opportunity to make a fortune before they are terminated and usually the recovery of the illegal amount is smaller than the total sum they have originally received. Secondly, failure to correctly apply the accountability rule happens when customs officers have a lack of accountability to enforce disciplinary actions. For example, the rules to charge corrupt customs officers are clearly stated but these are not being enforced correctly. Therefore, the perpetrators of customs corruption will go on unpunished.

\subsection{Internal Control}

Internal control is one of the most important mechanisms for organizations to monitor and control their operations. According to the Auditing Practices Board (APB, 1995) the internal control system can be defined as a whole set of controls and financials which enables management to run an efficient business, safeguard assets and protect themselves against errors and fraud. Based on Jones (2008), effective internal control procedures must consist of five main components, which include control environment, risk assessment, information and communication, monitoring and control activities. Thus, internal control is important and every organization must implement a good internal control procedure in their organization. The public sector is also not excluded from implementing a good internal control system, more so as they are responsible in handling public funds and trusts. According to Holtfreter (2004), a good system of internal controls will help to deter and prevent corruption from occurring within the organization.

In relation to customs corruption, poor internal control occurs when the customs management fail to implement a set of controls to monitor and manage their whole operation. Customs often deal with imports and exports of goods, thus, these activities will give the customs officials the opportunity to seize these goods illegally and use them for their own private benefit. Due to an inefficient internal control system such as lack of segregation of duties, physical safeguards, independent checks, proper authorization and proper document and records, the customs officers can easily disobey the rules and regulations that have already been set in the internal controls. Furthermore, with regards to procedures such as charges and penalties imposed by customs, the customs officers are free to manipulate the way they exercise their controlling rights. This usually occurs due to lack of proper implementation of internal controls (McLinden, 2005; Wonyra, 2018).

\subsection{Discretionary Power}

Discretionary power is a power granted to the officials by statute or delegation. This power does not impose an obligation on a decision-maker to exercise it or to exert it in a particular manner. The power must be exercised in accordance with legal requirements. It must be used reasonably, impartially and with the aim of avoiding oppression or unnecessary injury. Furthermore, Davis (1972, pp.4), defined discretion as follows: "A public officer has discretion whenever the effective limits on his power leave him free to make a choice among possible cause of action or inaction". According to Wade and Forsyth (1994), discretionary power can be easily recognized by the permissive statutory language that confers them. It is a signal by the use of words in empowering provisions such as "may" or "it shall be lawful". This concept gives the idea of an absence of decisive rules and regulations governing an economic activity, which can also be used to manage all types of contingencies that could arise (Myint, 2000). Therefore, it gives the relevant officials flexibility in interpreting and implementing the rules. In addition, Apaza 
(2012) stated that bureaucrats' expertise allow them to exercise discretion in the delivery of public services. It is intended to increase effectiveness and efficiency. However, discretion may be used as a tool for corruption. Nevertheless, a decision on whether or not to reduce bureaucrats' discretion depends on the public service being delivered.

In relation to customs corruption, discretionary power gives the idea that management gives customs officers extensive discretion in their daily routine operations. Customs officers are the primary enforcers of various customs procedures such as differential tariffs, anti-dumping measures, rules of origin, trade embargoes and quantitative restrictions (Gill, 2001; Tyagi \& Siddiqui 2017). These procedures are complex because different aspects of import and export controls are being used. Import of goods is based on the guidelines on the goods that can be easily imported and prohibited goods must be subjected to import license requirements. Meanwhile, export of goods is based on granting incentives to these goods in specific preconditions. Thus, complications like these give customs officers great discretionary power in applying the procedures according to the situations at hand. This can make it more difficult for legal authorities to charge the irresponsible officers at any given time, thus, allowing these customs officers to have more discretion in their daily routine operations. According to Tarar (2010), customs procedures are often outdated and must be amended regularly to keep it up-to-date with changing circumstances. By not doing so, a customs officer has a high discretion to disobey the rules and avoid getting caught by legal authorities. In addition, some officers did not refer to the quoted prices given by the customs management. This situation will give the customs officers wider discretion to value the goods and assess the customs duty and taxes.

\subsection{Underpinning Theoretical Perspectives}

\subsubsection{Agency Theory}

According to Jensen and Meckling (1976), agency theory is a contract whereby one or more persons (principal) engage another person (agent) to perform some service on the principal's behalf. This usually involves delegating certain decision-making authority to the agent. The principal will provide some capital to the agent thus, assuming a level of risk. The principal also expects the agent to perform a specific job, to run and control the organization, protect the principal's interest and act responsibly as a steward. Therefore, the agent must act honestly in the principal's best interest.

However, the agency theory problem is the principal's goals may differ from the agent's goals. The self-interest factor suggests that the agent is motivated to pursue his personal desires. According to Eisenhardt (1988), agency theory is based on assumptions that agents are rational. However, they possess a strong sense of self-interest and are risk-averse individuals. Risk aversion implies that agents may shift as much risk as possible to the principal when acting on their own behalf. Besides that, the agent can also exploit the situation and give disadvantages to the principal. Thus, the agent's behavior will work against the interest of the principal. The principal is often not privy to what the agent is doing. This situation will create a conflict of interest between the principal and the agent. In fact as Moe (1984) noticed, there is no guarantee that the agent will do what is in the best interests of his principal. By the same token, there is no guarantee that the agent will not be involved in corruption. The likelihood of corruption definitely threatens the principles of the agency theory.

According to Rothstein and Toerell (2008), the principal-agent relationship is a useful analytical framework to explore the factors that influence corruption between principal and agent in the public sector. Their study has found that corruption occurs when the agent practices low accountability and high discretionary power against the principal's instruction. Other studies by Banfield (1975) and Rose-Ackerman (1975) also supported the usage of the principal-agent model to determine the factors that influence corruption. Banfield (1975) found that a main factor that influences the agent's decision to be involved in corrupt activities is when an agent does not follow the internal control procedures given by the principal. In addition, Rose-Ackerman (1975) stated that an agent engages in corrupt activities and has conflicts of interest with the principal when the agents have monopoly power over the client. Weak accountability of the agents to the principal also fuels the likelihood of these agents being involved in corrupt practices. Hence, this model will focus on the relationship between the principal (top level government) and the agent (an official) who takes bribes from a private individual interested in the governments' goods. This can be applied to the situation in the Royal Malaysian Customs Department whereby officers and staffs may have conflicting interests when performing their duties and thus, will result to corruption. In the Royal Malaysian Customs Department, the customs officers are the agents of the principal (the federal government) to realize the goals and objectives of the federal government. Therefore, the agent's (customs officer) goals must be in conformity with the principal's (the federal government) goals to achieve efficient reform. 
The agency theory objective is to determine the optimal contract between principal and agent. Thus, this theory can be used as a relevant perspective in identifying various factors behind principal and agent differences when carrying their duties that lead to corrupt practices. This theory is also useful in understanding the factors that influence corruption (level of accountability, internal control and discretionary power) between the principal (Federal Government) and the agent (Royal Malaysian Customs Officer).

\section{Hypothesis Development}

\subsection{Level of Accountability and Corruption}

The concept of accountability refers to the proper observance of rules and regulations and the requirement that the customs officers will be held accountable for their actions. Many prior studies found that there is a negative relationship between control of corruption and accountability. When officials have high accountability, they tend to be less involved in corrupt activities and can do a better job in controlling corruption (Brewer et al., 2007; Unaam, Adim \& Adubasim 2018). Moreover, it also can increase their enforcement for business conduct and detecting fraud and corruption (Mirenda and Tewarie, 2014; Wadmany \& Melamed 2018). Some researchers claim the importance of implementing high level of accountability and transparency will likely reduce corruption. It observed that when legal officials do not disclose the legal report regarding the organization's information when they are required to do so, a rise in corruption occurs (Schaeffer, 2002; Stapenhurst and Langseth, 1997). Furthermore, a practice of high accountability able the government to separate the power between the legislature, executive, judiciary, media and others to combat corruption (Osborne, 2004), reduce the political corruption (Ionescu, 2015) and decrease the occurrence of autocratic systems whereby one person rules with unlimited authority (Mota and Carson, 2016). Hence, the first hypothesis is proposed as follows:

H1: There is a significant relationship between level of accountability and the perception on corruption in the Royal Malaysian Customs Department.

\subsection{Internal Control and Corruption}

To ensure that customs officers are all able to mitigate corruption, they need to know and follow the internal control procedures; otherwise, it can negatively affect the customs department as a whole. Prior literatures found that there is negative relationship between internal control and corruption. Weak internal control is susceptible to corporate corruption (Ge et al., 2014), it also increase the probability of management to practice corruption and make the organization unreliable in the eyes of investors (Lansiluoto et al., 2016; Umaru \& Ombugus 2017) and create negative impact on the organization (Sun, 2016). In addition, other studies found that when strong internal controls are adopted in the organization, it will likely improve the investment decision (Cheng et al., 2013), increase the firm's operating efficiency and performance (Feng et al., 2015), reduces the unintentional errors in the financial reporting and consequently, a more accurate financial input is achieved and corruption is reduced (Ashbaugh-Skaife et al., 2008).

However, a study made by Lin et al. (1998) contradicted these findings whereby it is indicated that policy-driven changes in the internal control system and its procedures are less effective in reducing corporate corruption. Hence, the second hypothesis is proposed as follows:

H2: There is a significant relationship between internal control and the perception on corruption in the Royal Malaysian Customs Department.

\subsection{Discretionary Power and Corruption}

The concept of discretionary power comprises the idea of an absence in the rules and regulations that govern an economic activity. Discretionary power gives the customs officer some flexibility in interpreting and implementing the rules. Many prior literatures found that there is positive relationship between discretionary power and corruption. The studies found that corruption is linked to discretionary power being misused in order to violate an explicit or implicit agreement (Schweitzer, 1991). Moreover, the abuse of discretionary powers can lead to errors and corruption (Swart, 1996), and in the long term, this will create economic disparities, reduce economic developments and decrease entrepreneurial investments (Eagles, 2015). A firm might practice corruption to get a discretionary judgement in their favour (Tenenbaum, 1996). Furthermore, study by Colombatto (2001) stated the practice of high discretionary power should be removed to eliminate corruption. Likewise, Gwilliams and Gorham (2015) also supported the view that when public officials exercise discretion, bias judgements and poor decisions occur as a result.

However, some researchers disputed these findings where it is declared that practice of high discretionary power is necessary for a society (Schalkwyk, 2004) and it is good to give discretion to the bureaucrats since they have the 
expertise to do their jobs well (Merton, 1957). Furthermore, Cook (2000) also argued that bureaucrats deserve discretion because they conduct themselves with integrity and exercising high discretion is wise for public officials (Bol et al., 2015). Therefore, the practice of discretionary power is the right thing to do, as it will not lead to corruption. Thus, the third hypothesis is proposed as follows:

H3: There is a significant relationship between discretionary power and the perception on corruption in the Royal Malaysian Customs Department.

\section{Methodology}

This study focused on the perceived factors for customs corruption in the Royal Malaysian Customs Department. In this study, the dependent variable is perception on corruption, which can be explained by multiple factors such as level of accountability, internal control and discretionary power (independent variables). The data was collected using stratified random sampling and the questionnaires was personally administrated by the researcher to a total of 180 customs officers in nine departments in Kelana Jaya; which are, Enforcement Department, Compliance Management Department, Customs Department, Good and Service Tax Department, Technical Services Department, Management Services and Human Resources Department, Corporate Planning Department, Legal Department and Information Technology Department.

The surveys were distributed directly to the officers at the middle of March 2016. In order to maximize the response rate, purposive sampling was used in data collection. The initial surveys involved officers participated in the Appreciation Event held on April 2016, General Meeting held on early May 2016 and Good \& Services Tax Seminar held on mid-May 2016. Six weeks after the initial distribution a total of 149 surveys had been completed. A follow-up visit and telephone calls in mid-May 2016 resulted in a total of 166 surveys being completed and returned. Therefore, this research has achieved an overall good response, as the response rate for this research is $92 \%$. According to Hagger et al. (2003), a good research should achieve a response rate of more than $50 \%, 60 \%$ or $75 \%$.

\subsection{Measurement of the Variables}

To measure the variables, this study used the 5-point Likert scale consist of 10 questions each for each variables. For the perception on corruption, the participants were asked on seven common aspects such as corruption in public officials, strength and effectiveness of anti-corruption efforts, international outlook, awareness, cautionary steps and public life. Moreover, for the level of accountability, the participants were asked on six common aspects such as effectiveness, quality, transparency, competence, compliance, and recording and reporting standard. In addition, for the internal control, the participants were asked on five common aspects such as good control environment, good control activities, good risk assessment, monitoring and good communication and information. Lastly for the discretionary power, the participants were asked on three common aspects such as self-determination, impact and power distance.

\subsection{Reliability of Instruments}

The reliability test was conducted to ensure that the measurement of the variables consistently reliable. According to George and Mallery (2003), the reliability test can be interpreted by using the rule of thumb. Based on Table 1, the Cronbach's Alpha for the Perception on Corruption subscale has high reliability where the Cronbach's $\alpha=.845$ with 10 items which is also considered as good consistency by George and Mallery (2003). Level of Accountability and Discretionary Power subscales also had high reliability where the Cronbach's $\alpha=.825$ and .880 with 10 items each. This also showed that both the independent variables had good consistency based on George and Mallery (2003). However, the Internal Control subscale had average reliability where the Cronbach's $\alpha=.784$ with 10 items which is considered as acceptable consistency by George and Mallery (2003). All the dependent and independent variables have a total of 40 items with all variables consisting of 10 items each.

Table 1. Reliability test

\begin{tabular}{lll}
\hline & Cronbach's Alpha & N of items \\
\hline Perception on Corruption & .845 & 10 \\
\hline Level of Accountability & .825 & 10 \\
\hline Internal Control & .784 & 10 \\
\hline Discretionary Power & .880 & 10 \\
\hline
\end{tabular}




\section{Findings and Discussion}

\subsection{Pearson's Correlation Coefficient Test}

This study conducted a Pearson's correlation coefficient test to measure the strength between the variables. Hinkle, Wiersma and Jurs (1998) have indicated a certain interpretation on the coefficient value whereby their study displayed that a coefficient with a range from .90-1.00 has a very high (positive/negative) correlation. Then, a coefficient with a range from .70-.90 has high (positive/negative) correlation. Next, a range from .50-.70 coefficient indicates moderate (positive/negative) correlation where else a coefficient range from .30-.50 has a low (positive/negative) correlation. Lastly, a coefficient range from .00-.30 has a little (positive/negative) correlation.

Based on Table 2, it shows that there is a high negative correlation with a coefficient of $r=-.752$ with p-value less than .01 between Perception on Corruption with the Level of Accountability. This could indicate there is a negative relation between the two variables whereby an increase in perception on corruption will likely decrease the level of accountability and vice versa. In addition, there is a moderate negative correlation with a coefficient of $r=-.574$ with p-value less than .01 between the Perception on Corruption and Internal Control. This could also indicate that there is a negative relationship between the two variables, where an increased perception on corruption will likely result to a decrease in internal control and vice versa. However, the result in this study demonstrated that there is a low positive correlation with a coefficient of $\mathrm{r}=.375$ with p-value less than .05 between Perception on Corruption and Discretionary Power. This could imply a positive relationship between the two variables, where an increase in perception on corruption will likely increase the discretionary power and vice versa.

Table 2. Pearson's correlation coefficient test

\begin{tabular}{llllll}
\hline & & $(1)$ & $(2)$ & $(3)$ & $(4)$ \\
\hline Perception on Corruption & $(1)$ & 1.000 & & & \\
\hline Level of Accountability & $(2)$ & $-.752^{* *}$ & 1.000 & & \\
\hline Internal Control & $(3)$ & $-.574^{* *}$ & $.468^{*}$ & 1.000 & \\
\hline Discretionary Power & $(4)$ & $.375^{*}$ & $.644^{* *}$ & $.689^{*}$ & 1.000 \\
\hline
\end{tabular}

Note: $* \mathrm{p}<.05, * * \mathrm{p}<.01$

Meanwhile, the study found that there is a low positive correlation with a coefficient of $r=.468$ with $p$-value less than .05 between Level of Accountability with Internal Control. This could indicate that there is a positive relationship between the variables, meaning that an increase in the level of accountability will likely increase the internal controls and vice versa. In addition, the study found that there is a moderate positive correlation with a coefficient of $\mathrm{r}=.644$ with p-value less than .01 between Level of Accountability and Discretionary Power. This could indicate that there is a positive relationship between the variables, whereby an increase in the level of accountability will likely increase the discretionary power and vice versa. Lastly, the study also found that there is a moderate positive correlation with a coefficient of $\mathrm{r}=.689$ with p-value less than .05 between Internal Control and Discretionary Power. Therefore, it shows that there is a positive relationship between the variables, and thus suggesting that an increase in internal control will likely increase the discretionary power and vice versa.

\subsection{Multicollinearity Test}

Multicollinearity test was carried out to examine the existence of a strong correlation between two or more predictors (independent variables) in a regression model. This test was also used to avoid bias in a model with the existence of two or more predictors. According to Field (2013), if multicollinearity exists between predictors, it becomes impossible to obtain unique estimates on the regression coefficients. One way of identifying multicollinearity is to look at collinearity diagnostics, which is the variance inflation factor (VIF). The VIF indicates whether a predictor has a strong linear relationship with the other predictor. Related to the VIF is the tolerance statistic, which is the reciprocal (1/VIF). According to Bowerman and O'Connell (1990), if the VIF is larger than 10 then there is cause for concern and the regression may be biased. In addition, Menard (1995) stated that if the tolerance is below .2, a potential problem is indicated. Moreover, Field (2013) stated that a good model is when the VIF is less than 10 and tolerance is between the range of .2 and .9 . 
Therefore, based on Table 3, the VIF for all three independent variables is below ten. This indicates that the variables are suited to predict the independent variables and the variables are not biased. Meanwhile, the tolerance for all the independent variables falls within the range of .2 and .9 , which indicates that there is no potential problem in these variables. It can be concluded that this study is in good motion and it is in good fit. Thus, the study may proceed to run the multiple regression test.

Table 3. Multicollinearity test

\begin{tabular}{lll}
\hline & VIF & Tolerance (1/VIF) \\
\hline Level of Accountability & 1.043 & .959 \\
\hline Internal Control & 1.059 & .944 \\
\hline Discretionary Power & 1.051 & .951 \\
\hline
\end{tabular}

\subsection{Multiple Regressions Test}

The multiple regression test was conducted to predict the value of a dependent variable based on the value of the independent variables. This test was also done to explain the effect of changes in the independent variables towards the dependent variable. In other words, a multiple regression was calculated to predict the perception on corruption based on the level of accountability, internal control, and discretionary power.

Table 4 shows the results obtained from conducting the multiple regression test. A significant regression equation was found $\mathrm{F}(3,162)=104.639, \mathrm{p}<.001$, with and $R^{2}$ of .660 and adjusted $R^{2}$ of .648. Based on the $R^{2}$ of .660, this indicates that perception on corruption is influenced by $66 \%$ by level of accountability, internal control and discretionary power, while the rest $(100 \%-66 \%=44 \%)$ is explained by other causes. In addition, the $\mathrm{F}$ value of 104.639 is significant at $\mathrm{p}<.001$, this implies that the multiple regression models can be used to predict the perception on corruption. In other words, level of accountability, internal control and discretionary power are simultaneously significant effects on the perception on corruption. This study on the Royal Malaysian Customs officials predicted that perception on corruption is equal to the following formula: Perception on Corruption = $14.991-.502$ (Level of Accountability) - .758 (Internal Control) + .387 (Discretionary Power), whereby the level of accountability, internal control and discretionary power are measured as percentages. The percentage of corruption decreased by $50.2 \%$ for each level of accountability, decreased by $75.8 \%$ for each internal control and increased by $38.7 \%$ for each discretionary power. In other words, a decrease in corruption will likely increase the level of accountability, increase the internal control and decrease the discretionary power. Therefore, level of accountability, internal control and discretionary power are significant predictors of the perception on corruption.

Table 4. Multiple regression test on the perception on corruption

\begin{tabular}{llll}
\hline Variables & $B$ & Std. Error & $\beta$ \\
\hline Constant & 14.991 & 3.065 & \\
Level of Accountability & -.502 & .062 & $-.512^{* *}$ \\
\hline Internal Control & -.758 & .101 & $-.495^{* * *}$ \\
\hline Discretionary Power & .387 & .085 & $.299^{* * *}$ \\
\hline$R^{2}$ & & .660 & \\
Adjusted $R^{2}$ & & .648 & \\
\hline$F$ & & $104.639^{* * *}$ & \\
\hline
\end{tabular}

Note: $* \mathrm{p}<.05, * * \mathrm{p}<.01, * * * \mathrm{p}<.001$

\section{Results and Discussion}

The result of this study provides information regarding the Customs officials' perception on corruption. The major finding of this study is that a significant relationship exists between the level of accountability, internal control and 
discretionary power with the perception on corruption. Firstly, this result supports the studies that emphasized the importance of the level of accountability as one of the factors influencing corruption (Brewer et al., 2007; Mirenda and Tewarie, 2014, Schaeffer, 2002; Osborne, 2004; Stapenhurst and Langseth, 1997; Ionescu, 2015; Mota and Carson, 2016). The result showed that there is a high influence of level of accountability towards corruption. As Koberg et al. (1999) stated accountability tends to enhance capabilities, provide opportunities for effective problem solving and encourage individual trust, thus enabling individuals to combat corruption. Based on the multiple regression results in this study, it denotes that accountability provides a negative relationship with corruption. When belief in the accountability of an individual such as his credibility, reliability, competence, and transparency increases, the overall corruption decreases. This result might mean that when individuals become aware that they will be held accountable for their wrongdoings, and they believe that every individual must be competent, reliable, credible and transparent, they will probably be willing to complete their tasks or jobs without errors and on a timely manner. Thus, this will then reduce the perception on corruption. Therefore, this predicts that the level of accountability is a good variable and hence, its influence towards the perception on corruption can be examined.

Secondly, this result also supports studies that advocated the importance of internal control as one of the factors influencing corruption (Ge et al., 2014; Feng et al., 2015; Cheng et al., 2013; Ashbaugh-Skaife et al., 2008; Sun, 2016; Lansiluoto et al., 2016). The findings show that there is a high influence of internal controls towards corruption. As Jiang et al. (2010) stated, a strong internal control lowers the risk of corruption. This is because a stricter internal control and monitoring environment would make it harder for the management to engage in corrupt activities that are harmful to stakeholders. Based on the multiple regression result in this study, internal control has a negative relationship with corruption. This result provides an idea that when an organization adopts a strong internal control system, the opportunities for individuals to engage in corrupt activities will be much less. However, the effectiveness of internal controls might be compromised if management decides to ignore the internal control procedure and override it at will. Therefore, this predicts that internal control is a good variable and thus, its influence towards the perception on corruption can be studied.

Thirdly, this result also endorses studies that stressed upon the importance of discretionary power as one of the factors influencing corruption (Schweitzer, 1991; Swart, 1996; Colombatto, 2001; Tenenbaum, 1996; Eagles, 2015; Gwilliams and Gorham, 2015). The result demonstrates that discretionary power has a high influence on corruption. Discretionary power reflects autonomy in the initiation and continuation of work behavior and processes such as making decisions about work methods, effort and pace (Spector, 1986). The study by Spector (1986) also noted that organizations that practice high discretion towards their management in decision-making processes would create corruption on a larger scale. Based on the multiple regression test result, this study has found that there is a positive relationship between discretionary power and corruption. This result put forward the insight that when individuals have high discretionary power in workplaces, the more likely they will engage in corrupt activities. This issue is similar to Denmark's (1993) findings in which he discovered that the higher the discretionary power, the higher the likelihood of individuals perceiving themselves to be corrupt. Thus, an individual who holds great discretionary power will feel more at ease to be involved in corrupt activities. Although a higher position does not necessarily provide more power for customs officials but it certainly strengthens the position of the official in question. As a consequence, these officials are able to conduct corrupt activities without being questioned. Hofstede (1993) also discussed that individuals with centralized authority are more accustomed to having high discretionary power thus, enabling them to practice corrupt activities. On the other hand, individuals working in decentralized organizations are more adapted to having lower discretionary power where everyone is being treated equally, are consulted upon and work is being delegated by a higher authority. Therefore, this predicts that discretionary power is a good variable and hence, its influence towards the perception on corruption can be studied.

Lastly, this result also supports prior studies that emphasized the usage of the Agency theory for corruption (Rothstein and Toerell, 2008; Banfield, 1975; Rose-Ackerman, 1975). Theoretically, the presumption made in the Agency theory is that the principal (federal government) and the agent (Royal Malaysia Customs officer) have certain conflicts of interest between them and the agent also exploits the authority given to him for his own private benefits. The agency theory problem specifies that the principal's goal may differ from the agent's goal. According to Alchian and Demsetz (1972), when conflicts of interest exist in an organization, it will eventually lead to corruption. Thus, the principal must monitor the agent's performance or attempt to align the agent's interest with the principal's interest. This will help to reduce conflicts of interest as well as corruption. Based on the results of this study, the Agency theory problem, which refers to the principal and the agent having a conflict of interest between each other, is accepted. This is because there could be a possibility that the agent (Royal Malaysian Customs officers) may exploit the authority given by the principal (Federal Government) when they practice low accountability, low 
internal control and high discretionary power in their jobs and result to engage in corrupt activities. Therefore, the Agency theory is a good underpinning theory to be used to study the influencing factors on corruption.

After conducting and reviewing the statistical analysis, the result of the hypotheses testing that was presented in the previous chapter is determined whether it can be accepted or rejected. The statistical analysis using the Pearson's Correlation Coefficient Test has proven that there is an existence of a relationship between the variables. Meanwhile, the Multiple Regression Test has also proven that the result accepted all the predicted hypotheses in this study. Therefore, based on Table 5, it shows that all the hypotheses that were predicted in this study are accepted.

Table 5. Hypotheses and results

\begin{tabular}{llll}
\hline Hypotheses & Prediction & Result \\
\hline H1: & $\begin{array}{l}\text { There is a significant relationship between level of accountability } \\
\text { and perception on corruption in the Royal Malaysia Customs }\end{array}$ & Accepted \\
Department. & $\begin{array}{l}\text { There is a significant relationship between internal control and -ve } \\
\text { perception on corruption in the Royal Malaysia Customs } \\
\text { Department. }\end{array}$ & Accepted \\
\hline H2: & $\begin{array}{l}\text { There is a significant relationship between discretionary power and +ve } \\
\text { perception on corruption in the Royal Malaysia Customs } \\
\text { Department. }\end{array}$
\end{tabular}

\section{Summary and Conclusions}

The findings found that level of accountability and corruption are related with each other as there is a negative relationship between these two. When there is a decrease in the level of accountability of an individual, it will likely increase the chances of him engaging in corrupt activities. Many of the officers in the Royal Malaysian Customs Department practice high accountability where they must follow the Code of Conduct to avoid getting penalized by the federal government. Hence, any officer who goes against the Code of Conduct will be held liable for their actions. This is consistent with the establishment of the integrity branch in the Royal Malaysian Customs Department in 2013. This branch was established to integrate all management matters related to the integrity and accountability of officers under an umbrella that is specifically intended to implement a more focused and structured system. Thus, the elements of integrity, accountability, prevention, compliance and detection of misconduct can be enforced efficiently and optimum success can be achieved.

The findings also discovered that internal control and corruption have an influence on each other as there seems to be a negative relationship between both variables. When there is a decline in the internal control procedure in an organization, it will likely increase the probability of an individual in the organization to be involved in corruption. The Royal Malaysian Customs officers have their own internal control policies and procedures that their department needs to strictly abide. Accordingly, the Royal Malaysia Customs Department (RMCD) Strategic Plan 2015-2019 was launched. This strategic plan is a formal written document that contains the department's policies and procedures as well as programs to achieve strategic goals of the organization in a timely manner. The main components of the strategic plan include the vision, mission, strategic issues, strategic trust and actions plan for all customs officers. It is a guide for all officers to follow in order to increase the internal controls of the department and it is hoped that by doing so, the department will be a leading world-class agency.

In addition, the findings also found that discretionary power has a strong impact on corruption in the Royal Malaysian Customs Department as there is a positive relationship between these two. When there is an increase in an individual's discretionary power, it will likely increase the chances of the individual to be implicated in corrupt activities. The Royal Malaysian Customs officers are strictly forbidden from practicing high discretion towards their customers as it is against their ethical code of conduct to do so. There is also the perception that customs officers do not practice high discretionary powers in their department. This is supported by evidence from the customs department itself whereby officers are given the Customs Act 1967 which prohibits them from engaging in corrupt activities using their discretionary power. If a customs officer commits any wrongdoings, he will be penalized and be held liable for his actions. Therefore, corrupt activities will lessen when customs officers have less discretion. 
The result in this study has proven that the Royal Malaysian Customs Department are aware of corruption cases occurring in their department. They also perceive that corruption in their department may have been influenced by the three predictors in this study, which are level of accountability, internal control, and discretionary power. However, more improvements are still needed in the near future to fully combat corruption and to also prevent incidences of corruption from becoming worse.

The findings in this study offer knowledge to the Royal Malaysian Customs regarding the risk of corruption in their own department. The outcome of this study will raise awareness amongst customs officers regarding corrupt activities in their department. Most customs officers are certainly aware of these activities but they might be too afraid to take any actions. Thus, this study aims to shed some knowledge on how to combat corruption and create a better and healthier environment for the customs department. Moreover, this study contributes to the present literature on corruption in Malaysian public sector organizations. Accordingly, academicians and researchers may develop new frameworks or techniques on other influencing factors of corruption that will be helpful in determining the cause of corruption and how to combat it.

The limitation in this study is the scope of this study is limited to determining the influence of level of accountability, internal control, and discretionary power in pervasive corruption in the Royal Malaysian Customs Department. A review of the literature shows that there are many factors that can cause customs corruption such as the political environment, transparency, personal and monopoly. Consequently, the process of obtaining information was extremely difficult with regards to the sensitivity of the Royal Malaysian Customs Department. The findings can only be interpreted using the questionnaire rather than an in-depth interview with key important personnel.

The findings of this study are encouraging as it exposes a number of areas for further research. The first recommendation would be to investigate the relationship between certain personality factors. The findings of this study did not investigate personality factors such as trust, wages and salaries and others. Some researchers may find that corruption only happens because of external factors only and not due to internal factors. Therefore, it is wise to do further extensive research on the personal factors that may contribute to corruption. Second recommendation is to conduct in-depth interviews and focus groups discussions with a follow-up sample of respondents because it may generate additional information as compared to what was obtained using survey instruments only.

\section{Acknowledgement}

The authors would like to acknowledge the support provided by the Ministry of Education (MOE) Malaysia and Accounting Research Institute of Universiti Teknologi MARA for the funding received [600-RMI/ARI_IRES 5/3 (3/2016)].

\section{References}

Alchian, A. A., \& Demsetz, H. (1972). Production, Information Costs, and Economic Organization. American Economic Review, 62(5), 777-795.

Apaza, C. (2012). Public Management Challenges Ensuring Accountability and Controlling Corruption, The Public Purpose. Public Administration Journal, 4(5), 45-59. https://doi.org/10.1017/S1049096512000303

APB. (1995). Accounting and Internal Control Systems SAS 300. Auditing Practices Board Statements of Auditing Standards London, 3(2), 112-200.

Ashbaugh-Skaife, H., Collins, D., Kinney, W., \& LaFond, R. (2008). The Effect of Internal Control Deficiencies and Their Remediation on Accrual Quality. The Accounting Review, 83(7), 217-250. https://doi.org/10.2308/accr.2008.83.1.217

Banfield, E. C. (1975). Corruption as a Feature of Governmental Organizations. Journal of Law and Economics, 18(3), 587-605. https://doi.org/10.1086/466826

Bol, J. C., Hecht, G., \& Smith, S. D. (2015). Managers' Discretionary Adjustments: The Influence of Uncontrollable Events and Compensation Interdependence. Contemporary Accounting Research, 2(1), 223-300. https://doi.org/10.1111/1911-3846.12070

Bowerman, B. L., \& O’Connell, R. T. (1990). Linear Statistical Models: An Applied Approach (2nd ed.). California: Belmont Duxbury.

Brewer, G. A., Choi, Y., \& Walker, R. M. (2007). Accountability, Corruption and Government Effectiveness in Asia: An Exploration of World Bank Governance Indicators. International Public Management Review, 8(2), 200-219. 
Cheng, M., Dhaliwal, D., \& Zhang, Y. (2013). Does Investment Efficiency Improve After the Disclosure of Material Weaknesses in Internal Control Over Financial Reporting?. Journal of Accounting and Economics, 56(1), 1-18. https://doi.org/10.1016/j.jacceco.2013.03.001

Colombatto, E. (2001). Discretionary Power, Rent-Seeking and Corruption. ICER Working Paper, 9(2), 1-23. University of Torino.

Cook, J. R. (2000). Public Service to Serve the Public. In Transparence International Source Book, 12(1), 23-45.

Customs Annual Report. (2015). Customs Annual Report 2015. Royal Malaysian Customs Department. Retrieved May 31, 2016, from http://www.customs.gov.my/ms/mp/Pages/mp_publ.aspx

Davis, K. C. (1972). Administrative Law Text (3rd ed.). West: St. Paul, Minnesota.

Denmark, F. L. (1993). Women, Leadership and Empowerment. Psychol Women Q, 17(2), 343-356. https://doi.org/10.1111/j.1471-6402.1993.tb00491.x

Eagles, M. T. (2015). Exploring Potential Associations with the Presidential Discretionary Power of FEMA Funds Dispensation. Managerial Auditing Journal, 31(1), 1-112.

Eisenhardt, K. M. (1988). Agency-theory and Institutional-theory Explanations - The Case of Retail Sales Compensation. Academy of Management Journal, 3(3), 488-511. https://doi.org/10.2307/256457

Feng, M., Li, C., McVay, S., \& Skaife, H. (2015). Does ineffective internal control over financial reporting affect a firm's operations? Evidence from firm's inventory management. The Accounting Review, 48(4), 190-209. https://doi.org/10.2308/accr-50909

Field, A. (2013). Discovering Statistics Using IBM SPSS Statistics (4th ed.). Washington DC: SAGE Publications Ltd.

Ge, W., Li, Z., Liu, Q., \& McVay, S. (2014). The Effect of Internal Control on Corporate Corruption: Evidence from China. Journal of Business Management, 7(2), 67-87.

George, D., \& Mallery, P. (2003). SPSS for Windows Step by Step: A Simple Guide and Reference 11.0 Update (4th ed.). Boston: Allyn and Bacon.

Gill, J. (2001). Customs: Developing an Integrated Anti-Corruption Strategy. World Bank Institute, Washington, DC, $5(5), 129-138$.

Gwilliams, I., \& Gorham, S. (2015). How Discretionary Is a U.K. Employer's Discretion?. Employee Relations Law Journal, 41(3), 64-67.

Hagger, M., Wilson, S., Pollak, T., \& Rooney, P. (2003). Response Rates for Mail Surveys of Non-Profit Organizations: A Review and Empirical Test. Journal of Business Management, 8(2), 122-130.

Hinkel, D. E., Wiersma, W., \& Jurs, S. G. (1998). Applied Statistics for the Behavioural Sciences (4th ed.). Boston: Houghton Mifflin Company.

Hofstede, G. (1993). Cultural Constrains in Management Theories. Acad Manage Exec, 7(2), 81-94. https://doi.org/10.5465/ame.1993.9409142061

Holtfreter, K. (2004). Fraud in US Organizations: An Examination of Control Mechanism. Journal of Business, 12(1), 88-95. https://doi.org/10.1108/13590790510625070

Husted, B. W. (1994). Honour among Thieves. Business Ethics Quarterly, 1(1), 17-27. https://doi.org/10.2307/3857556

Ionescu, L. (2015). Electoral Accountability and Political Corruption. Economics, Management, and Financial Markets, 10(3), 63-68.

Jensen, M. C., \& Meckling, W. H. (1976). Theory of the Firm: Managerial Behavior Agency Costs and Ownership Structure. Journal of Financial Economics, 3(4), 305-360. https://doi.org/10.1016/0304-405X(76)90026-X

Jiang, G., Lee, C., \& Yue, H. (2010). Tunnelling Through Intercorporate Loans: The China Experience. Journal of Financial Economics, 98(5), 1-20. https://doi.org/10.1016/j.jfineco.2010.05.002

Jones, M. J. (2008). Internal Control, Accountability and Corporate Governance. Accounting, Auditing \& Accountability Journal, 21(7), 1052-1075. https://doi.org/10.1108/09513570810907474 
Koberg, C. S., Boss, R. W., Senjem, J. C., \& Goodman, E. A. (1999). Antecedents and Outcomes of Empowerment. Group Organ Manage, 24(1), 71-92. https://doi.org/10.1177/1059601199241005

Lambsdorff, J. G. (2007). The Institutional Economic of Corruption and Reform: Theory, Evidence, and Policy. Cambridge University Press. https://doi.org/10.1017/CBO9780511492617

Lansiluoto, A., Jokipii, A., \& Eklund, T. (2016). Internal Control Effectiveness - A Clustering Approach. Managerial Auditing Journal, 31(1), 5-34. https://doi.org/10.1108/MAJ-08-2013-0910

Lin, J., Chai, F., \& Li, Z. (1998). China's Economic Reforms: Some Unfinished Business. American Economic Review, 88(2), 422-427.

McLinden, G. (2005). Customs Modernization Handbook: Integrity in Customs. World Bank, Washington, DC.

Menard, S. (1995). Applied Logistic Regression Analysis. Sage University Paper Series on Quantitative Applications in the Social Sciences. California: Thousand Oaks Sage.

Merton, R. K. (1957). Social Theory and Social Structure. Glencoe Illinois: Free Press.

Mirenda, A., \& Tewarie, S. (2014). Best Practices in Preventing Fraud and Corruption in Global Business. Lex Mundi, 11(4), 89-100.

Moe, T. (1984). The New Economics of Organization. American Journal of Political Science, 28(6), 67-79. https://doi.org/10.2307/2110997

Mota, P. M., \& Carson, L. (2016). Brazilian Anti-Corruption Legislation and Its Enforcement: Potential Lessons for Institutional Design. Journal of Self-Governance and Management Economics, 4(1), 34-71. https://doi.org/10.22381/JSME4120162

Myint, U. (2000). Corruption: Causes, Consequences and Cures. Asia-Pacific Development Journal, 7(8), 33-58.

Ndonga, D. (2013). Managing the Risk of Corruption in Customs through Single Window Systems. World Customs Journal, 7(2), 23-37.

Nwabuzor, A. (2005). Corruption and Development: New Initiatives in Economic Openness and Strengthened Rule of Law. Journal of Business Ethics, 59(1/2), 121-138. https://doi.org/10.1007/s10551-005-3402-3

Osborne, D. (2004). Transparency and Accountability Reconsidered. Journal of Financial Crime, 11(3), 292-300. https://doi.org/10.1108/13590790410809239

Palmer, M. (2000). Record Management and Accountability versus Corruption, Fraud, and Maladministration. Records Management Journal, 10(2), 61-72. https://doi.org/10.1108/EUM0000000007256

Rose-Ackerman, S. (1975). The Economics of Corruption. Journal of Public Economics, 4(6), 187-203. https://doi.org/10.1016/0047-2727(75)90017-1

Rothstein, B., \& Toerell, J. (2008). What is Quality of Government? A Theory of Impartial Government Institutions. Governance: An International Journal of Policy, Administration, and Institutions, 21(2), 165-190. https://doi.org/10.1111/j.1468-0491.2008.00391.x

Schaeffer, M. (2002). Corruption and Public Finance. Management Systems International, 26(7), 340-360. https://doi.org/10.1108/10222529200400021

Schalkwyk, L. V. (2004). The Discretionary Powers of the Commissioner for the South African Revenue Service Are They Constitutional?. Meditari Accountancy Research, 12(2), 165-183.

Schweitzer, A. G. (1991). Aspects of the Administrative Law Relationship between Taxpayer and the CIR. LLM Thesis, 6(8), 1-60. University of Cape Town, Cape Town.

Spector, P. E. (1986). Perceived Control by Employees: A Meta-Analysis of Studies Concerning Autonomy and Participation at Work. Human Relation, 39(3), 1005-1016. https://doi.org/10.1177/001872678603901104

Stapenhurst, F., \& Langseth, P. (1997). The Role of the Public Administration in Fighting Corruption. International Journal of Public Sector Management, 10(5), 311-330. https://doi.org/10.1108/09513559710172131

Sun, Y. (2016). Internal Control Weakness Disclosure and Firm Investment. Journal Accounting, Auditing and Finance, 31(2), 277-307. https://doi.org/10.1177/0148558X15598027

Swart, G. J. (1996). Constitutional Limitations on the Delegation of Powers of Taxation. SA Publiekreg, 11(2), 446-471. 
Tadaro, M., \& Smith, S. (2003). Economic Development (8th ed.). Boston, Massachusetts: Pearson Addison Wesley.

Tarar, S. (2010). Corruption in Customs Department: An Analysis of Klitgaard Framework, paper presented at Back to the future. EURAM (European Academy of Management) 2010 Conference, 6(3), 1-23. Rome.

Taruvinga, R., Gachira, W., Chiwanza, W., \& Nkomo, D. J. (2017). Comparison of the Lee-Carter and Arch in Modelling and Forecasting Mortality in Zimbabwe. Asian Journal of Economic Modelling, 5(1), 11-22. https://doi.org/10.18488/journal.8/2017.5.1/8.1.11.22

Tenenbaum, B. (1996). What the Prime Minister Need to Know. Electricity Journal, 9(2), 23-36. https://doi.org/10.1016/S1040-6190(96)80182-5

Tyagi, S., \& Siddiqui, S. (2017). Yield Curve and Momentum Effects in Monthly US Equity Returns: Some Nonparametric Evidence. Asian Journal of Economics and Empirical Research, 4(2), 61-67. https://doi.org/10.20448/journal.501.2017.42.61.67

Umaru, R. I., \& Ombugus, D. A. (2017). Determinants of job satisfaction of Colleges of Education Lecturers: A study of Nasarawa State College of Education, Akwanga. Asian Business Research Journal, 2(1), 8-13. https://doi.org/10.20448/journal.518.2017.21.8.13

Unaam, A. O., Adim, C. V., \& Adubasim, E. I. (2018). Employee Loyalty and Organizational Citizenship Behaviour in the Port Harcourt Area Command of the Nigeria Police Force. International Journal of Business, Economics and Management, 5(6), 135-145. https://doi.org/10.18488/journal.62.2018.56.135.145

Wade, H. W. R., \& Forsyth, C. F. (1994). Administrative Law (7th ed.). Oxford: University Press.

Wadmany, R., \& Melamed, O. (2018). "New Media in Education" MOOC: Improving Peer Assessments of Students' Plans and Their Innovativeness. Journal of Education and e-Learning Research, 5(2), 122-130. https://doi.org/10.20448/journal.509.2018.52.122.130

Wonyra, K. O. (2018). Impact of Telecommunications Market Liberalization on Labor Productivity in Economic Community of West African States. Journal of Social Economics Research, 5(2), 63-74. https://doi.org/10.18488/journal.35.2018.52.63.74

World Bank. (1997). The Role of the World Bank. Helping Countries Combat Corruption, 7(8), 556-570. Washington, DC.

Zimring, F., \& Johnson, D. (2005). On the Comparative Study of Corruption. British Journal of Criminology, 45(6), 793-809. https://doi.org/10.1093/bjc/azi042 